\title{
Arithmetic in Higher Education-A Learning Acquired in Elementary Education
}

\author{
Lizzeth Navarro-Ibarra $^{1} \&$ Omar Cuevas-Salazar ${ }^{1}$ \\ ${ }^{1}$ Instituto Tecnológico de Sonora, Mexico \\ Correspondence: Lizzeth Navarro-Ibarra, Instituto Tecnológico de Sonora, Cd. Obregón, Sonora, Mexico. E-mail: \\ Lizzeth.Navarro@gmail.com
}

Received: August 7, 2020

Accepted: October 23, 2020

Online Published: January 27, 2021

doi:10.5539/ies.v14n2p54

URL: https://doi.org/10.5539/ies.v14n2p54

\begin{abstract}
This research arises as a necessity to solve deficiencies in basic mathematics in university students. The objective was to determine the effect on academic achievement when implementing a didactic strategy for learning arithmetic. The study design is pre-experimental with pretest and post-test. The participants of the experiment are freshman year students for the bachelors in engineering program. 332 students participated in the research, who studied five topics in the didactic strategy. The data were collected with quizzes before and after each learning activity. The data analysis technique carried out was the Mann-Whitney $U$ test for independent samples. Academic achievement improved in four subjects. For this reason, it can be established that the design and implementation of the didactic strategy benefit the students by allowing them to remember a topic in an environment that provides instruction and instant feedback.
\end{abstract}

Keywords: arithmetic, technology, learning environment, first-year university student

\section{Introduction}

The world education challenge for this century is to solving long-term and short-term problems, within the community at first and with other regions afterwards (Collado-Ruano, 2016). The United Nations Educational, Scientific and Cultural Organization (UNESCO) committed to encourage quality education and improve learning results, for which it is required to optimize resources, processes, and progress evaluation. Furthermore, it points out that quality education stimulates creativity, knowledge, and ensures the acquisition of basic reading, writing, and calculus competencies. Also, quality education promotes the necessary abilities for problem-solving and other cognitive, personal and social abilities. This is to develop competencies, values, and attitudes that allow them to confront the challenges that arise (UNESCO, 2016).

Occupational and life abilities have evolved, where certain cognitive and socioemotional abilities dominate physical skills. Currently, mathematical reasoning and appropriate use of language are essential cognitive abilities, as well as self-sufficiency or perseverance within socioemotional abilities. These abilities seem to have more impact on people's quality of life as of countries (Barniell et al., 2016).

There is a great correlation in the necessity to prepare for a job as there is to everyday life (Gravemeijer, Stephan, Julie, Lin, \& Ohtani, 2017). These authors say everyday life is where self-confidence and sufficiency must be developed when dealing with math situations and lead an active citizenship. However, this should not diminish the importance of curricular mathematics or their value as part of a cultural inheritance (Gravemeijer et al., 2017). For Arcavi (2016) mathematical education should qualify students so that they and by self-interest be the ones that identify the mathematical information involved in practically all situations surrounding them, be them numerical, geometric, probabilistic, or logical.

Clements, Sarama, and Germeroth (2016) suggest that high-quality mathematical education can have a double benefit, the teaching of an area of important content and to develop some of the execution processes. These processes imply that the student can control, supervise or regulate their own thought process and behavior. This allows the improvement of learning and problem-solving capacity. Albeit, academic achievement in mathematics differs notably among countries. The average achievement among 15-year-old youths differs in more than two standard deviations, which is equivalent to six to eight years of learning, which is among the countries with the heist and lowest results (Woessmann, 2016). 
There are international evaluations for measuring academic achievement such as PISA, which is applied every three years among the countries that are part of the Organization for Economic Co-operation and Development (OECD) to 15-year-old youths. This evaluation determines students' knowledge and abilities in Science, Math, Reading, collaborative problem solving, and financial education (OECD, 2019). In the Mathematics area for the 2015 evaluation, Mexican students obtained 408 points, leaving them below the average which is 490 for the countries that belong to the OECD. Which is to say, 57\% of students don't reach the basic level competency, which means that only occasionally can they carry out routine procedures such as arithmetic operations where they are given every instruction, however, they have difficulty representing in mathematical form a simple real-life situation (PISA, 2019)?

Within our nation, Mexico has available the Planea national evaluation which is applied to 9th grade students. The test evaluates key learning for Language and communication, and Mathematics, which are relevant and vital for the acquiring new knowledge and timeless. In 2017 67\% of students were located in the lowest Mathematics achievement level. This level indicates that they can solve problems that require comparing or competing for operations using natural numbers. The basic decimal and fractional operations correspond to levels two and three, respectively (PLANEA, 2019).

In present days the formation of a citizen is given both by formal and informal channels of education, and in both cases Information and Communication Technologies (ICT) have a strong influence (Cabero, 2015). A new educational system that is being integrated with new learning alternatives which are rapidly growing. ICT are supporting these learning alternatives, such as home schooling, video games, eLearning, learning in the workplace, web communities and distance learning (Collins \& Halverson, 2018).

Considering all the aforementioned about the possibilities of ICT in teaching and learning mathematics, this is how the research question arises: What effect does the implementation of the didactic strategy on arithmetic have in students' academic achievement?

In order to give answer to that question, the objective is set as follows: Determine the effect in academic achievement when implementing the didactic strategy for learning arithmetic.

\section{Literature Review}

Within learning institutions, the most important shift in the educational paradigm is the focus in results and information and accepting responsibility over students' success. Universities can, by leading by example, turn into a priority promoting and supporting student's learning. Nonetheless, students continue to be the main responsible for their own learning (Boggs, 2019).

For that purpose, the constructivism theory contributes with important elements to consider in the education of students. This learning theory is formed by different psychological and educational research trends such as the Piaget's genetic theory, Vigotsky's sociocultural theory, Ausubel's meaningful learning, and Bruner's cognitive psychology. In constructivism, the individual's cognitive and social aspects of behavior and affective aspects are not a result of the environment or internal dispositions, but a construction of their own that is continually generated as a product of the interaction of these factors. Therefore, knowledge is a construct of the human being derived from models he already possesses, which is to say, of what he has already constructed within the environment he interacts with (Carretero, 1997).

A relevant contribution by Vigotsky (1978), is the concept of zone of proximal development (ZPD) which refers to the distance of the actual level of development, determines by the capacity of independently solving a problem and the potential level of development, established by the capacity if solving a problem with the aid of an adult or in collaboration with another more capable partner. The mentioned above is completed with four points: a) what is presently done with the aid of a more knowledgeable person about a certain topic will, in time, be possible to be done without aid, b) Performance autonomy is achieved as a result of the support received giving place to a dynamic relationship between learning and development, c) it is a superior psychological process by being an organized learning, which in turn converts to a mental development and drives evolutionary mechanisms, and d) the interaction between people with varying levels of knowledge should be through teaching-learning situations that generate development (Baquero, 1997).

By the end of the learning period, it is expected that the student has comprehended and acquired the meaning of taught concepts and ideas. The learning evidence is found in the retention of meaning and transfer of knowledge, ascertained by the application of the acquired meanings (Ausubel, 2000).

According to Bruner, the learning theory must consider the student's personal factors such as interest, curiosity, pleasure, and the desire to learn, among others. Likewise, the syllabus should be set accordingly to the level of 
development in the student, it should also make the student aware of the importance of his efforts for the achievement of long-term goals. Because the latter Bruner specifies that feedback should be immediate, the results should be made known when solving a problem. The lesson where knowledge is obtained by discovery is what may impart the student trust in himself, liberating him from external motivation (Oyarbide, 2004).

Moreover, the development of ICT has influenced the present day's teaching methods. The web offers the capacity to communicate vastly but at a fraction of the cost. The ways of interacting in the web can include text, voice, video, and anyone of them. Furthermore, transmission can be synchronous, asynchronous or nearly asynchronous (Anderson, 2016).

Ifenthaler (2018) defines digital learning as any group of methods based in technology applied to support the learning processes. Likewise, for Weller (2007), electronic learning is any instruction experience that uses technology related to the use of the Internet to a certain extent.

In the design and implementation of a virtual learning environment, digital activities and students should be the teaching process core. Also, they must include active methodologies using ICT (Silva, Fernández, \& Astudillo, 2016). At the same time this creates new roles for the students, requiring from them to be autonomous workers and learners (Alvarado \& Barba, 2016; Reigeluth, 2016).

Teaching and learning in a virtual environment entail two types of interpretations the student must make. One is the content the student must learn. The second is the interpretations on the meaning, motives and necessities that content satisfies for the student and the change of perception of himself in his learning achievement. These interpretations are given shape in a dynamic and contextual way by the individual himself derived from his interaction with the learning environment (Onrubia, 2005).

Within the virtual environment, the learning activities have to stimulate the student to construct knowledge through the recollection of contents, the processing of the same, and assigning practical usefulness. In addition, digital resources determine the participant's interest and progress. It is fundamental for the latter to have clear and precise wording of the activities' instructions so they guide the student with a certainty of actions to take (Moreira-Segura \& Delgadillo-Espinoza, 2015).

An important role of technology, according to Reigeluth (2016), is to evaluate the knowledge that is integrated by the instruction, tasks and actual performance, grade assignment and formative feedback. Van der Kleij, Feskens, and Eggen (2015) conducted a meta-analysis with 40 studies about the effects of feedback methods in computer-based teaching environments. The results suggested that immediate feedback most effective for low order learning than when feedback is delayed, but a significant interaction couldn't be found.

\section{Methodology}

The present study is of pre-experimental type with pretest and post-test. Didactic strategy for learning arithmetic was designed for university students. The design was implemented in the Instituto Tecnológico de Sonora, university located to the Norwest of Mexico. The participants were chosen with an assessment test applied to newly registered students who entered the subject Fundamentos de Matemáticas (Mathematics Basics). The students who scored lower than five were asked to attend a mathematics laboratory as a remedial course to level their math skills. Attendance to the lab was not compulsory, having a total attendance of 332 students to perform the virtual activities.

The lab has 21 desktop computers with virtual activities about arithmetic and algebra. The activities were hosted on a free web page (Wix) in order to organize the topics and sequence of steps to follow. Each activity is started and ended with a quiz (five questions). These quizzes were done in Google Forms (open and free software) providing immediate feedback to the students. The initial and final quiz correspond to the pretest and post-test for each activity.

For each activity the objective of the same was shown, as well as the approximate duration for the activity. The activities were constituted by steps to indicate the sequence to follow. Step one always showed an educational video as an introduction to the topic. Step two was an activity with exercises where the student answered questions about what was seen during the video, having their answers immediately validated. Afterward another video with other subtopics could be shown, thereafter more exercises to answer. Depending of the topic's complexity tutorials were included, where the process for answering was explained in detail. The activities with exercises and tutorials were elaborated in Active Presenter.

For arithmetic, the first section of activities corresponds to the topics of integer and decimal numbers. This section is comprised of five activities described in Table 1. 
Table 1. Activities that integrate the topic of integer and decimal numbers

\begin{tabular}{lc}
\hline Description & Estimated time (min) \\
\hline Activity 1: Integers in the numbers line & 30 \\
Activity 2: Decimals and fractions in the numbers line & 45 \\
Activity 3: Prime numbers & 30 \\
Activity 4: Lowest common multiple & 45 \\
Activity 5: Greatest common divisor & 45 \\
\hline
\end{tabular}

Activity 1 which is about integers in the numbers line is formed by three steps. An educational video in step 1, exercises about locating the natural numbers in the numbers line and in step 3, exercises to locate positive and negatives in the numbers line. The number lines exercises used vary in their scale. For each exercise the value of the scale is indicated, so that the student identifies the following values and can point the location of the number asked for. For the exercises about locating natural numbers, lines were given with a point located at the zero mark and the instruction is made to displace it to a certain value. If the location is correctly made, a congratulations message is displayed, or on the contrary, the message invites to try again because the answer is incorrect. For the negative and positive location in the numbers line exercises, the student must now write down the value a given position represents. In the numbers line certain information about the scale is provided so that the student can deduce the value of each division or step in the line. Likewise, for all steps the feedback is immediate.

Decimal and fractional numbers make up the Activity 2, which integrates six steps, three of which are educational videos and the other three are exercises. The first step is a video explaining negative decimals, therefor, step 2 is exercises about the same. For the activity about negative decimal, horizontal and vertical lines are drawn for which the student has to locate the position of the negative number given, be it by writing the number or choosing the correct option. Step 3 is a video about fractions in the numbers line and step 4 are exercises about identifying fractions in the numbers line. In the activity for fractions in the numbers line there are exercises where the student has to write down the fraction represented by the point given in the line, others are multiple choice or to move a small circle to the fraction that is asked for. Rational numbers are explained through a video on step 5 and afterwards exercises are given where they have to identify them un a numbers line in step 6 . In the activity for the last step mentioned the exercises present various numbers line and the student has to identify which of them have the correct placement of the numbers required by the exercise. Also, there are exercises where they have to identify a certain location when knowing the value for other locations within a line without a drawn scale. On all exercises the student gets back instant validation of their answers to corroborate if they answered correctly or not, reflect upon it and try again.

Activity 3, prime numbers, contains two videos and one tutorial with exercises. In step 1 the video explains which are the prime and composite numbers. Step 2 shows a video about prime numbers factoring. Step 3's tutorial asks to identify the prime numbers in a $10 \times 10$ matrix, numbers from 1 to 100 . Twin primes are also defined and they are asked to select the existing twin numbers from 1 to 100 . Then there are exercises to indicate if a number is a prime number or composite. And lastly, the prime factors of a series of numbers are asked for. For each problem in the tutorial there is immediate feedback, so the student has confirmation of the answer.

Lowest common multiple (LCM) is the topic for activity 4 . This virtual activity is made up by a video, two exercise practices and a tutorial. Step 1 consists in a video where LCM is defined and how to calculate it. In step two there are exercises where they are asked to obtain the LCM of a pair of numbers, after three wrong attempts, a detailed explanation of how to obtain the correct value is provided. Step 3 is a tutorial that presents four problems with everyday life situations where they have to answer by obtaining the LCM. Each problem from the tutorial is explained at the time it is being answered. Step 4 asks to solve two problems of everyday life situations, where the correct answer is displayed for each after three failed attempts to answer.

In activity 5 the greatest common divisor (GCD) topic is studied. A video, two practices with instant feedback exercises and a tutorial are included for this activity. The video in step 1 defines the concept of GCD and explains how to obtain said value. Step 2 contains a problem practice where the GCD is required to be calculated for pairs of numbers. For each exercise a correct answer is given, provided there are three failed answer attempts. Step 3 corresponds to the tutorial in which four common real-life situations are presented which require to be answered by obtaining the value of the GCD. The answering process is presented for each of the problems. Step 4 includes two common real-life situation problems, with a detailed description of the solution in case of a wrong answer.

The procedure used in this research is described below: 
1) A didactic proposal was made by elaborating activities for each topic. Educational videos were searched for each topic and interactive exercises and tutorials were done for each topic.

2) The didactic proposal was implemented in the mathematics Laboratory of the university where students could attend Monday to Friday from 10:00 to 18:00 hrs.

3) For each activity students answered the initial quiz, at the end of the topic they answered the final quiz, which correspond to the pretest and post-test respectively. The quizzes were answered in the computer and each was comprised of five multiple choice questions.

4) The tests were automatically graded informing the student of their score and capturing the grade in an electronic sheet.

5) The information was analyzed with the statistical program "Statistical Package for the Social Sciences" (SPSS 23). The test used for each activity is the Mann-Whitney U test for independent samples.

\section{Results}

The research question inquiries on the effect of implementing a didactic strategy for learning arithmetic has on students' academic achievement. To answer such a question, the objective set was to determine the effect on academic achievement by implementing a didactic strategy for learning arithmetic in freshmen university students.

The achievement was evaluated by applying a knowledge exam as a pretest and post-test to the student group. The instrument has a 1 to 10 scoring.

The data distribution is not normal, so non-parametric statistical tests were applied for independent samples following the procedure conducted by various studies (Cabero \& Llorente, 2006; Navarro-Ibarra, Cuevas, Peralta, \& Ansaldo, 2017). The statistical analysis was carried out with the Mann-Whitney U test.

Table 2 presents the values obtained with the Mann-Whitney U test for activity 1: Integer numbers. The average score and its sum for the pretest are higher than that of the post-test.

Table 2. Mann-Whitney U test for Activity 1 : Integer numbers

\begin{tabular}{cccc}
\hline Group & $\mathrm{N}$ & Average score & Sum of scores \\
\hline Pretest & 332 & 332.01 & 110226 \\
Post-test & 317 & 317.66 & 100699 \\
\hline
\end{tabular}

Contrast statistics were obtained in order to determine if significant differences were presented. This analysis, between the pretest and post-test, was conducted with the Man-Whitney U test, Wilcoxon $\mathrm{W}$ test and $\mathrm{Z}$ statistic (see Table 3). The significance obtained is .296, which is greater than .01; because of that it can be established there is equality between the pretest and post-test. This means there is no difference in academic achievement.

Table 3. Contrast statistics between the pretest and post-test in Activity 1: Integer numbers

\begin{tabular}{cccc}
\hline Mann-Whitney U test & Wilcoxon W test & $Z$ & Sig. \\
\hline 50296 & 100699 & -1.045 & .296 \\
\hline
\end{tabular}

Table 4 shows for activity 2: Decimals and fractions in the numbers line, results of the data provided by the Mann-Whitney $\mathrm{U}$ test. The average score and sum of scores for the post-test are greater than the pretest.

Table 4. Mann-Whitney U test for Activity 2: Decimals and fractions numbers

\begin{tabular}{cccc}
\hline Group & N & Average score & Sum of scores \\
\hline Pretest & 321 & 243.77 & 78250 \\
Post-test & 286 & 371.60 & 106278 \\
\hline
\end{tabular}

The contrast statistics of the Mann-Whitney U test, Wilcoxon W and Z, were calculated to determine significant differences between the pretest and post-test. Table 5 shows significance of .000 that means differences between the pretest and post-test. The sum of scores and the average score of the post-test are greater than those of the pretest. Therefore, the academic achievement improved by the didactic strategy. 
Table 5. Contrast statistics between the pretest and post-test in Activity 2: Decimals and fractions numbers

\begin{tabular}{cccc}
\hline Mann-Whitney U test & Wilcoxon W test & Z & Sig. \\
\hline 26569 & 78250 & -9.248 & .000 \\
\hline
\end{tabular}

The results for the Mann-Whitney U test applied to activity 3: Prime numbers are shown in Table 6. Table 6 shows that the sum of scores and their average are higher in the post-test.

Table 6. Mann-Whitney U test for Activity 3: Prime numbers

\begin{tabular}{cccc}
\hline Group & N & Average score & Sum of scores \\
\hline Pretest & 296 & 259.75 & 76886.5 \\
Post-test & 291 & 328.84 & 95691.5 \\
\hline
\end{tabular}

To determine if the differences between the pretests and post-test are significant the contrast statistics of Mann-Whitney $\mathrm{U}$ test, Wilcoxon $\mathrm{W}$ and $\mathrm{Z}$ tests were conducted. Table 7 shows the values calculated where there is a .000 significance which confirms there are differences between the pretest and post-test. The sum of scores and their average for the post-test are higher than those of the pretest, which leads us to say that the academic achievement improved by undertaking the didactic strategy.

Table 7. Contrast statistics between the pretest and post-test in Activity 3: Prime numbers

\begin{tabular}{cccc}
\hline Mann-Whitney U test & Wilcoxon W test & Z & Sig. \\
\hline 32930.5 & 76886.5 & -5.151 & .000 \\
\hline
\end{tabular}

The Mann-Whitney U test was applied to the information gathered from Activity 4: Lowest common multiple, whose results are detailed in Table 8. The sum of scores and average for the post-test are higher than the pretest.

Table 8. Mann-Whitney U test for Activity 4: Lowest common multiple

\begin{tabular}{cccc}
\hline Group & N & Average score & Sum of scores \\
\hline Pretest & 282 & 198.87 & 56082 \\
Post-test & 265 & 353.95 & 93796 \\
\hline
\end{tabular}

Table 9 presents the contrast statistics employed to verify a significant difference between the pretest and post-test. The .000 significance means there are significant differences between the pretest and post-test. The sum of scores and average from the post-test is higher than the pretest, demonstrating that the virtual activity for this topic leads to an improvement in the students' academic achievement.

Table 9. Contrast statistics between the pretest and post-test in Activity 4: Lowest common multiple

\begin{tabular}{cccc}
\hline Mann-Whitney U test & Wilcoxon W test & $\mathrm{Z}$ & Sig. \\
\hline 16179 & 56082 & -11.757 & .000 \\
\hline
\end{tabular}

Table 10 gathers the results from the Mann-Whitney U test for Activity 5: Greater common divisor. The average score and the sum of scores from the post-test are greater than those from the pretest.

Table 10. Mann-Whitney U test for Activity 5: Greater common divisor

\begin{tabular}{cccc}
\hline Group & N & Average score & Sum of scores \\
\hline Pretest & 243 & 216.98 & 52725.5 \\
Post-test & 250 & 276.18 & 69045.5 \\
\hline
\end{tabular}

Table 11 contains the contrast statistics applied to determine significant differences between the pretest and 
post-test. A significance of .000 indicates there are in fact significant differences between the pretest and post-test. The sum of scores and average scores from the post-test are greater than the pretest, which confirms improved academic achievement after undergoing the virtual activity.

Table 11. Contrast statistics between the pretest and post-test in Activity 5: Greater common divisor

\begin{tabular}{cccc}
\hline Mann-Whitney U test & Wilcoxon W test & Z & Sig. \\
\hline 23079.5 & 52725.5 & -4.798 & .000 \\
\hline
\end{tabular}

Table 12 shows the averages obtained for the pretest and post-test in the five topics included in the didactic strategy. On integers, the difference between the pretest and the post-test is minimal and as the statistic of contrast indicated, it is not significant. In decimal and fractional numbers, prime numbers, minimum common multiple and maximum common divisor, the averages of the post-test are greater than those of the pretest.

Table 12. Average score between the pretest and post-test

\begin{tabular}{cccccc}
\hline $\begin{array}{c}\text { Average } \\
\text { score }\end{array}$ & $\begin{array}{c}\text { Integer } \\
\text { numbers }\end{array}$ & $\begin{array}{c}\text { Decimals and fractions } \\
\text { numbers }\end{array}$ & $\begin{array}{c}\text { Prime } \\
\text { numbers }\end{array}$ & \multicolumn{2}{c}{$\begin{array}{c}\text { Gowest common } \\
\text { multiple }\end{array}$} \\
\hline Pretest & 8.22 & 6.12 & 1.93 & 3.50 & 6.10 \\
Post-test & 8.25 & 7.89 & 3.07 & 7.21 & 7.63 \\
\hline
\end{tabular}

\section{Discussions and Conclusions}

In this paper, a research question was established, and according to it the objective of the research was established. The objective consisted in determining the effect in academic achievement when implementing a didactic strategy for learning arithmetic.

To determine the effect in academic achievement a statistical analysis was applied for independent samples for the five activities. For the integer numbers activity, it was found that the significance was greater than .01 for which there is no difference in academic achievement.

In the topic of decimal and fractions corresponding to activity two, it was observed that the post-test was higher than the pretest, which is evidence of learning. It was determined that in the prime numbers activity there was an improvement when completing the virtual activity. As for activity four, which was about lowest common multiple, an improvement in academic achievement was reached, just like for the greater common divisor activity.

This indicates that students have the integer numbers competence. However, in specific topics, knowledge is not preserved over the years. On the other hand, on the issue of prime numbers, although there was improvement in academic performance, this is very low. Therefore, the activities carried out for this topic should be reviewed to achieve better academic performance.

As remedial support for university students, the didactic strategy for learning arithmetic had proven to be effective by reaching the required learning. The development of digital activities where concepts are being built dynamically (Onrubia, 2005) and the active methodology mediated by ICT (Silva et al., 2016) encourages the student's work and autonomy (Alvarado \& Barba, 2016). This agrees with Vigotsky (1978) and Baquero (1997) who argue that the autonomy in performance is a product of the support received in the teaching-learning process.

Additionally, the design of activities that stimulate the interest and improvement in students give way to a virtual environment where the construction of knowledge is encouraged (Moreira-Segura \& Delgadillo-Espinoza, 2015). This is through already existing structures of the students and their interaction with the environment (Carretero, 1997), proving itself with the retention of meanings (Ausubel, 2000) proven in the evaluations.

Another of the factors that aided in the academic achievement improvement was immediate feedback, as stated in Bruner's cognitive theory. This theory stated that unobstructed knowledge of the results when answering a problem positively influences learning (Oyarbide, 2004). At the same time, Onrubia (2005) points out that there is a change in self-perception in the student, because of goals achieved. The use of ICT in the development of the virtual activities made it easy for the feedback to be instantaneous, as Reigeluth (2016) stated. Likewise, Van der Kleij et al. (2015) found that instant feedback is more effective than a delayed one.

High-quality universal education is independent of the economic resources; because of this, it is a viable objective that will benefit millions of students that today lack a better future (Schleicher, 2018). The inclusion of ICT in 
education, with their capacity for fast and economic information transmission (Anderson, 2016) is an opportunity for the proposal of new teaching alternatives.

The topics included in the didactic strategy are part of the expected learnings in basic education (SEP, 2017). However, the results indicate that learning was not achieved during those school years. On the other hand, the use of ICT can help students remember or learn these arithmetic topics again.

\section{Acknowledgments}

Publication financed with PROFEXCE 2020 resources.

\section{References}

Alvarado, M., \& Barba, M. (2016). Gestión del talento humano e innovación de la enseñanza y el aprendizaje. Bloomington: Palibrio.

Anderson, T. (2016). 3. Theories for Learning with Emerging Technologies. In G. Veletsianos (Ed.), Emergence and Innovation in Digital Learning. Foundations and Applications (pp. 35-50). Edmonton: Athabasca University Press. https://doi.org/10.15215/aupress/9781771991490.01

Arcavi, A. (2016). Miradas Matemáticas y Pensamiento Numérico. Avances de Investigación en Educación Matemática, 9, 11-19. https://doi.org/10.35763/aiem.v0i9.145

Ausubel, D. (2000). The Acquisition and Retention of Knowledge. A Cognitive View. New York, USA: Springer. https://doi.org/10.1007/978-94-015-9454-7

Baquero, R. (1997). Vigotsky y el aprendizaje escolar. Argentina: Aique Grupo Editor S. A.

Berniell, L., De la Mata, D., Bernal, R., Camacho, A., Barrera-Osorio, F., Álvarez, F., ... Vargas, J. F. (2016). RED 2016. Más habilidades para el trabajo y la vida: los aportes de la familia, la escuela, el entorno y el mundo laboral. Bogotá: CAF.

Boggs, G. (2019). Chapter One. The Learning Paradigm. In T. U. O'Banion (Ed.), 13 ideas that are transforming the community college world (pp. 33-50). Maryland: Rowman \& Littlefield.

Cabero, J. (2015). Reflexiones educativas sobre las tecnologías de la información y la comunicación (TIC). TCyE, 1, 19-27. Retrieve from https://tecnologia-ciencia-educacion.com/index.php/TCE/article/view/27

Carretero, M. (1997). Constructivismo y educación. México, D.F.: Editorial Progreso.

Clements, D., Sarama, J., \& Germeroth, C. (2016). Learning executive function and early mathematics: Directions of causal relations. Early Childhood Research Quarterly, 36, 79-90. https://doi.org/10.1016/j.ecresq.2015.12.009

Collado-Ruano, J. (2016). Una perspectiva transdisciplinar y biomimética de la educación para la ciudadanía mundial. Educere, 20(65), 113-129. Retrieve from http://erevistas.saber.ula.ve/index.php/educere/article/ view/11692

Collins, A., \& Halverson, R. (2018). Rethinking Education in the Age of Technology: The Digital Revolution and Schooling in America (2nd ed.). New York, NY: Teachers College Press.

Gravemeijer, K., Stephan, M., Julie, C., Lin, F., \& Ohtani, M. (2017). What Mathematics Education May Prepare Students for the Society of the Future? International Journal of Science and Mathematics Education, 15(1), 105-123. https://doi.org/10.1007/s10763-017-9814-6

Ifenthaler, D. (2018). Chapter 1. How We Learn at the Digital Workplace. In D. Ifenthaler (Ed.), Digital Workplace Learning: Bridging Formal and Informal Learning with Digital Technologies (pp. 3-8). https://doi.org/10.1007/978-3-319-46215-8_1

Moreira-Segura, C., \& Delgadillo-Espinoza, B. (2015). La virtualidad en los procesos educativos: reflexiones teóricas sobre su implementación. Tecnología en Marcha, 28(1), 121-129. https://doi.org/10.18845/tm.v28i1.2196

OCDE. (2019). Programme for International Student Assessment. Retrieve from $\mathrm{http}: / /$ www.oecd.org/pisa/aboutpisa/

Onrubia, J. (2005). Aprender y enseñar en entornos virtuales: actividad conjunta, ayuda pedagógica y construcción del conocimiento. RED Revista de Educación a Distancia, 2, 1-16. Retrieve from https://revistas.um.es/red/article/view/24721

Oyarbide, M. A. (2004). Jerome Seymour Bruner: De la percepción al lenguaje. Revista Iberoamericana de 
Educación, 33(7), 1-18. https://doi.org/10.35362/rie3412902

PISA. (2019). Resultados de PISA 2015. Nota país. México. Retrieve from https://www.oecd.org/pisa/PISA-2015-Mexico-ESP.pdf

PLANEA. (2019). Planea. Resultados nacionales 2017. $3^{\circ}$ de secundaria. Retrieve from http://planea.sep.gob.mx/content/general/docs/2017/RESULTADOS_NACIONALES_PLANEA2017.pdf

Reigeluth, C. (2016). Instructional Theory and Technology for the New Paradigm of Education. RED Revista de Educación a Distancia, 50, 1-17. https://doi.org/10.6018/red/50/1b

Schleicher, A. (2018). World Class: How to build a 21st-century school system. https://doi.org/10.1787/9789264300002-en

SEP. (2017). Aprendizajes clave para la educación integral. Ciudad de México: Secretaría de Educación Pública. Retrieve from https://www.planyprogramasdestudio.sep.gob.mx/descargables/biblioteca/secundaria/mate /1-LPM-sec-Matematicas.pdf

Silva, J., Fernández, E., \& Astudillo, A. (2016). Modelo interactivo en red para el aprendizaje: hacia un proceso de aprendizaje online centrado en el estudiante. Pixel-Bit. Revista de Medios y Educación, 49, 225-238. https://doi.org/10.12795/pixelbit.2016.i49.15

UNESCO. (2016). Educación 2030: Declaración de Incheon y Marco de Acción para la realización del Objetivo de Desarrollo Sostenible 4: Garantizar una educación inclusiva y equitativa de calidad y promover oportunidades de aprendizaje permanente para todos. Incheon: UNESCO. Retrieve from http://www.unesco.org/new/fileadmin/MULTIMEDIA/FIELD/Santiago/pdf/ESP-Marco-de-Accion-E2030aprobado.pdf

Van der Kleij, F., Feskens, R., \& Eggen, T. (2015). Effects of feedback in a computer-based learning environment on students' learning outcomes: A meta-analysis. Review of Educational Research, 85(4), 475-511. https://doi.org/10.3102/0034654314564881

Vigotsky, L. (1978). El desarrollo de los procesos psicológicos superiores. Barcelona, España: Grupo editorial Grijalbo.

Weller, M. (2007). Virtual Learning Environments. Using, choosing and developing your VLE. New York, NY: Routledge. https://doi.org/10.4324/9780203964347

Woessmann, L. (2016). The importance of school systems: Evidence from international differences in student achievement. Journal of Economic Perspectives, 30(3), 3-32. https://doi.org/10.1257/jep.30.3.3

\section{Copyrights}

Copyright for this article is retained by the author(s), with first publication rights granted to the journal.

This is an open-access article distributed under the terms and conditions of the Creative Commons Attribution license (http://creativecommons.org/licenses/by/4.0/). 